\title{
Correction to: Analysis and quantification of bone healing after open wedge high tibial osteotomy
}

\author{
E. Nemecek · C. Chiari · A. Valentinitsch · F. Kainberger · G. Hobusch · A. Kolb · L. Hirtler · C. Trost · S. Vukicevic · \\ R. Windhager
}

\section{Correction to:}

Wien Klin Wochenschr 2019

https://doi.org/10.1007/s00508-019-01541-8

The original version of this article unfortunately contained a mistake. The presentation of Tab. 4 was incorrect. The corrected table is given below.

The original article has been corrected.

The online version of the original article can be found under https://doi.org/10.1007/s00508-019-01541-8.

E. Nemecek · C. Chiari · G. Hobusch · A. Kolb · C. Trost · Prof. Dr. R. Windhager $(\bowtie)$

Department for Orthopedics and Trauma-Surgery,

Medical University of Vienna, Waehringer Guertel

18-20, 1090 Vienna, Austria

reinhard.windhager@meduniwien.ac.at
A. Valentinitsch · F. Kainberger

Department for Radiology, Medical University of Vienna, Vienna, Austria

\section{Hirtler}

Center for Anatomy and Cell Biology, Medical University of Vienna, Vienna, Austria

S. Vukicevic

Center for Translational and Clinical Research, University of

Zagreb, Zagreb, Croatia 
Table 4 Mean BMD measurement values in Hounsfield units $(\mathrm{HU})$ at baseline and follow-up; $p<0.0002$. Visualization of changes in BMD for each patient are displayed using

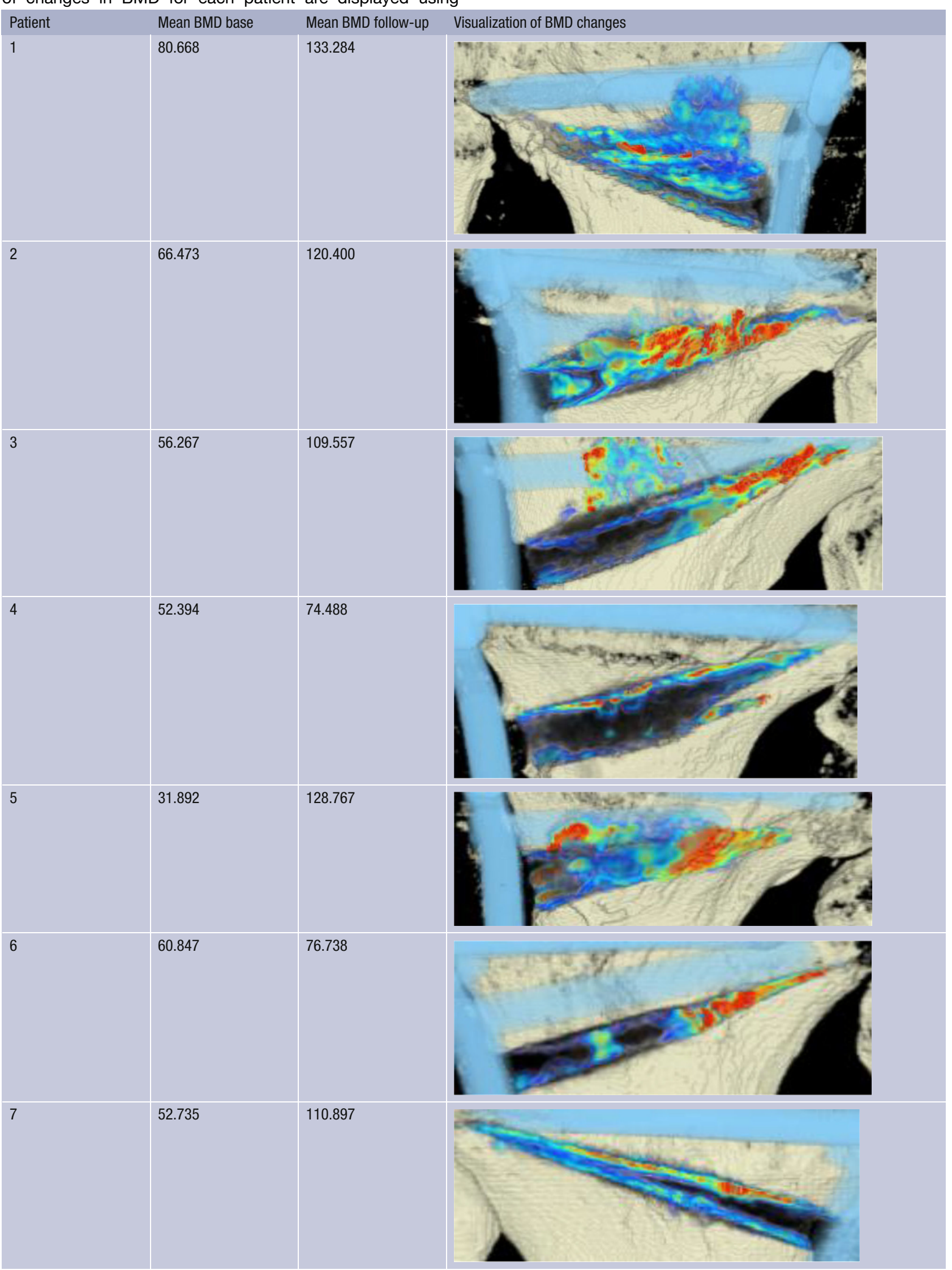

color coding (red= high bone growth, green= moderate bone growth, blue = low bone growth) 
Table 4 (Continued)

\begin{tabular}{|c|c|c|c|}
\hline Patient & Mean BMD base & Mean BMD follow-up & Visualization of BMD changes \\
\hline 8 & 58.040 & 178.214 & $\mathbf{n}$ \\
\hline 9 & 46.363 & 100.354 & \\
\hline 10 & 43.953 & 150.971 & \\
\hline 11 & 45.303 & 108.430 & \\
\hline 12 & 60.094 & 58.141 & \\
\hline $\begin{array}{l}\text { Mean BMD } \\
\text { (range) }\end{array}$ & $\begin{array}{l}54.586 \\
(31.892-80.668)\end{array}$ & $\begin{array}{l}112.487 \\
(178.214-58.141)\end{array}$ & $p<0.0002$ \\
\hline
\end{tabular}

